\title{
Field Comparison of Tensiometer and Granular Matrix Sensor Automatic Drip Irrigation on Tomato
}

\author{
Rafael Muñoz-Carpena', Michael D. Dukes ${ }^{2}$, Yuncong C. Li ${ }^{1}$, \\ and Waldemar Klassen ${ }^{1}$
}

ADDITIONAL INDEX WORDS. Water conservation, soil moisture sensors, soil tension, high frequency, vegetable crops, Lycopersicon esculentum

\begin{abstract}
Summary. A low-volume/high frequency (LVHF) soil moisture-based drip irrigation system was tested on a shallow sandy soil at a commercial tomato (Lycopersicon esculentum) farm in southern Florida. Six LVHF irrigation treatments were compared with the standard commercial practice on the farm (control), where a portable pump was used for manual drip irrigation twice each week. In the six LVHF treatments the system was continuously pressurized by means of an electrical pump and a pressure tank, and controlled by an irrigation timer set to irrigate a maximum of five times per day with the irrigation time (i.e., volume) set according to historical evapotranspiration (ET) demands in the area. Two treatments were based on timer schedules, one to supply $100 \%$ of the maximum recommended crop water needs in the area based on historical ET (ET-100\%), and the other to supply $150 \%$ of those needs (ET-150\%). The other four treatments were created by interfacing two types of soil moisture sensors (switching tensiometers and granular matrix sensors with control modules) set at two moisture points (wet $=10 \mathrm{kPa}$, optimal $=15 \mathrm{kPa}$ ) in a closed control loop with the irrigation timer programmed at the ET-100\% schedule. Results showed that the six LVHF treatments reduced water use while not significantly affecting tomato yields. Switching tensiometers at the $15 \mathrm{kPa}$ set point performed the best (up to $73 \%$ reduction in water use when compared to the control, $50 \%$ with respect to ET-100\%). The results show that water use below historical ET levels can be obtained without sacrificing yield by keeping the root zone moisture at controlled levels with the soil-moisture based system. Routine maintenance was critical for reliable operation of the switching tensiometers. Granular matrix sensor based irrigation behaved erratically, and did not improve water savings compared to ET-100\%, indicating that this system was not effective under the conditions of the area due to the sensor's slow response to frequent wetting-rewetting cycles and characteristics of the interface.
\end{abstract}

$\mathrm{T}$ Tomato growers in the United States are at a competitive disadvantage due to off-shore competition from countries where labor is considerably cheaper than in the U.S. Growers will be at an even greater disadvantage with the imminent phase-

${ }^{1}$ Tropical Research and Education Center, IFAS University of Florida, 18905 SW 280 St., Homestead, FL 33031

${ }^{2}$ Agricultural and Biological Engineering Department, University of Florida, Gainesville, FL 32611 ; tel: 352 392-1864; fax: 352-392-4092

The authors wish to dedicate this work to the late Dr. H. Bryan. We thank T.T. Dispenza, C. Kameko, M. Codallo, T. Olczyk, R. Regalado, and Q. Wang for their technical support. Pine Island Farms Inc. contributed with the use of experimental plot and $\mathrm{Mr}$. M. Knight (T-Tape Inc.) donated the drip tape used for the experiment. The use of trademarks does not imply the endorsement by the University of Florida. This research was supported by the Florida Agricultural Experiment Station and a grant(s) from Florida Tomato Committee and the Florida Fruit and Vegetable Association, and approved for publication as Journal Series No. R-10435. out of methyl bromide in the U.S. Through proper irrigation, average tomato yields in southern Florida can be maintained (or increased) while minimizing environmental impacts caused by excess applied water and subsequent nutrient leaching. Thus, improving irrigation efficiency can contribute greatly to reducing produc- tion costs of tomatoes making southern Florida's tomato industry more competitive and sustainable. Efficient and modern irrigation systems in Florida and other areas where soils with low water holding capacities and shallow rooted crops predominate should utilize the following irrigation principles: 1) low volume-high frequency, 2) soil moisture sensor based scheduling, and 3 ) automatic operation (Dukes et al., 2003). Soils with water holding capacities in the $4 \%$ to $8 \%$ range by volume (e.g., sands, gravels) are common in southern Florida and present special water management challenges $(\mathrm{Mu}-$ ñoz-Carpena et al., 2002).

Traditional irrigation based on low frequency (a few times per week) and a large volume usually results in over-irrigation in southern Florida soils. With this type of irrigation a large portion of the applied water percolates quickly to the shallow groundwater, potentially carrying with it nutrients and other agrichemicals applied to the soil. In addition, excess water in the root zone from excess irrigation or a high water table can reduce tomato yields (Wang et al., 2004).

As an alternative to traditional irrigation systems, a low volume of water can be applied frequently (several times per day) to maintain a desired moisture range in the root zone that is optimal for plant growth. LVHF also has the potential to minimize leaching. For LVHF systems, the target soil moisture is usually set in terms of soil tension or matric potential (expressed in $\mathrm{kPa}$ or cbar), or volumetric moisture (expressed in percent of water volume in a volume of undisturbed soil). Soil water tension is related to the amount of energy that has to be exerted by a plant to extract water from the soil. One other benefit of automatic irrigation techniques is convenience. In a previous experience working

\begin{tabular}{lllc}
\hline $\begin{array}{l}\text { Units } \\
\text { To convert U.S. to SI, } \\
\text { multiply by }\end{array}$ & U.S. unit & SI unit & $\begin{array}{l}\text { To convert SI to U.S., } \\
\text { multiply by }\end{array}$ \\
\hline 0.4047 & acre & $\mathrm{ha}$ & 2.4711 \\
1 & $\mathrm{cbar}$ & $\mathrm{kPa}$ & 1 \\
0.3048 & $\mathrm{ft}$ & $\mathrm{m}$ & 3.2808 \\
0.0929 & $\mathrm{ft}^{2}$ & $\mathrm{~m}^{2}$ & 10.7639 \\
3.7854 & $\mathrm{gal}$ & $\mathrm{L}$ & 0.2642 \\
2.5400 & inch(es) & $\mathrm{cm}$ & 0.3937 \\
25.400 & inch(es) & $\mathrm{mm}$ & 0.0394 \\
1.1209 & $\mathrm{lb} / \mathrm{acre}$ & $\mathrm{kg} \cdot h \mathrm{~h}^{-1}$ & 0.8922 \\
0.0254 & $\mathrm{mil}$ & $\mathrm{mm}$ & 39.3701 \\
28.3495 & $\mathrm{Oz}$ & $\mathrm{g}$ & 0.0353 \\
6.8948 & $\mathrm{psi}$ & $\mathrm{kPa}$ & 0.1450 \\
& & &
\end{tabular}


with a soil moisture based automatic irrigation system, Dukes et al. (2003) found that once the system is setup and verified, only weekly observation was required.

Soil moisture can be determined by direct (soil sampling) and indirect (soil moisture sensing) methods. Direct methods of monitoring soil moisture are not used for LVHF irrigation scheduling because they are intrusive and labor intensive and can not provide immediate feedback. Soil moisture probes can be permanently installed at representative points in an agricultural field to provide repeated moisture readings over time that can be used as a guide for irrigation scheduling. They generally can be used for manual readings to guide irrigation scheduling, while some of them can also be interfaced directly with the irrigation controller in a closed loop control system (Zazueta et al., 1994) to automate irrigation. Special care is needed when using soil moisture devices in coarse soils, especially in gravelly loam soils (Krome and Chekika series) present in southern Florida (Muñoz-Carpena et al., 2002). Most devices require close contact with the soil matrix that is sometimes difficult to achieve in these soils.

Tensiometers are among the most widely used tension-based soil moisture monitoring devices in Florida (Muñoz-Carpena et al., 2004; Zazueta and Xin, 1994). The device is based on the principle that when a sealed water-filled tube is placed in contact with the soil through a permeable and saturated porous material (ceramic cup), water inside the tube comes into equilibrium with the soil solution [i.e., it is at the same potential as the water held in the soil matrix (soil matric potential)]. Hence, the soil water matric potential is equivalent to the vacuum or tension created inside the tube. They can be used as stand-alone manual instruments or interfaced with an irrigation controller (switching tensiometers) for automatic watering. Switching tensiometers have been used in various applications such as fresh-market tomatoes (Clark et al., 1994; Smajstrla and Locascio, 1994), citrus (Citrusspp.) (Smajstrla and Koo, 1986), and bermudagrass (Cynodon dactylon) (Augustin and Snyder, 1984) in Florida to automatically control irrigation events based on preset soil matric potential limits. Smajstrla and
Koo (1986) discussed the problems associated with using tensiometers to initiate irrigation events in Florida. Problems included entrapped air in the tensiometers, organic growth on the ceramic cups, and the need for recalibration. Smajstrla and Locascio (1996) reported that using switching tensiometers placed at 6-inch depths and set at 10 and $15 \mathrm{kPa}$ tensions in a fine sandy soil in Florida reduced irrigation requirements of tomatoes by $40 \%$ to $50 \%$ without reducing yields. Li et al. (1998) showed that tensiometers can also be used successfully for manually scheduling tomato irrigation in calcareous gravelly soils (Krome series). In their study, optimal irrigation at $10 \mathrm{kPa}$ increased yield, improved fruit quality and reduced nutrient leaching. Wang et al. (2004) studied tomato yields in Krome soils with irrigation scheduled by manual readings from tensiometers. When compared to irrigation at $5 \mathrm{kPa}$ (control), they found that all three of the other higher tensions $(10,20$, and $30 \mathrm{kPa}$ ) used significantly improved yields of marketable, large and extralarge fruit. The highest yield increases were obtained at $30 \mathrm{kPa}$, and were about $29 \%, 28 \%$, and $22 \%$ greater than those at $5 \mathrm{kPa}$ (control) for yields of marketable, extra-large fruit, and large fruit, respectively.

Although used extensively to automate irrigation systems, tensiometers tend to require more maintenance compared to solid-state sensors such as granular matrix sensors (GMS). GMS are similar to tensiometers in that they are made of a porous material that reaches equilibrium with the soil moisture. The soil moisture tension is obtained using a calibration equation with the electrical resistance between electrodes embedded in the porous material (granular matrix block) inserted in the soil. These sensors have been used to automatically irrigate cotton (Gossipium spp.) (Meron et al., 1996), onion (Allium cepa), potato (Solanum tuberosum) (Shock et al., 2002), containerized plants (Hansen and Pasian, 1999), and urban landscapes (Qualls et al., 2001). Generally, GMS have been found to require less maintenance than traditional tensiometers. Similar to many of the automatic tensiometer controlled irrigation systems, Shock et al. (2002) described a system that used GMS to initiate a timed irrigation event. Although GMS provide a mechanism to control irrigation systems, these sensors with factory calibration equations for generic soil types may not provide adequate control for irrigation in coarse Florida soils (Irmak and Haman, 2001).

The objective of this work was to evaluate a LVHF automatic irrigation system interfaced with two different soil moisture sensor types in a commercial setting and compare it to the common grower practice in the area and scheduling methods using historical evapotranspiration. Water use, crop yields, advantages and disadvantages of the system and sensors are presented.

\section{Materials and methods}

FIELD EXPERIMENT SITE AND CROP MANAGEMENT. A research and demonstration project was conducted on a commercial tomato farm, Pine Island Farms, Miami, Fla. The experiment was conducted in a 1.5-acre experimental plot within a 40-acre commercial tomato field. The soil was Dade fine sand (12 inches overlaying porous limestone bed rock), hyperthermic, uncoated spodic Quartzipsamment (USDA, 1996). Tomatoes were grown on raised beds at 6 - $\mathrm{ft}$ spacing. Twin rows of drip tape [T-TAPE TSX 50812-450 (0.6-inch i.d., 12 -inch emitter spacing, 0.27 -gal $/ \mathrm{h}$ emitter discharge at 10 psi, 8-mil thick); T-Systems International, San Diego, Calif.] were laid on the beds and covered with plastic mulch according to local production practices (Table 1). During bed formation, fumigant [Dowfume MC-33 (2:1 volumetric mix of methyl-bromide: chloropicrin); Albemarle Corp., Baton Rouge, La.] was injected into the soil at $350 \mathrm{lb} /$ acre during the formation of the raised beds, and immediately thereafter the drip lines and plastic mulch were installed.

After the beds were prepared, planting was postponed 3 months due to a delay in obtaining the electrical power needed to operate the irrigation system. Tomato seedlings ('Florida 47') were transplanted on 4 Feb. 2003 at 24 inches apart along twin staggered rows that resulted in 7255 plants/acre and was identical to the commercial production system. After transplanting, all irrigation treatments and the control were irrigated alike for $10 \mathrm{~d}\left(2 \mathrm{~h} \cdot \mathrm{d}^{-1}\right)$ to promote seedling establishment. Irrigation treatments were initiated thereafter according to Table 2. Fertilizer injections (fertigation) were in accordance with the farmer schedule 
Table 1. Irrigation system specifications and relevant horticultural parameters for the tomato crop. ${ }^{2}$

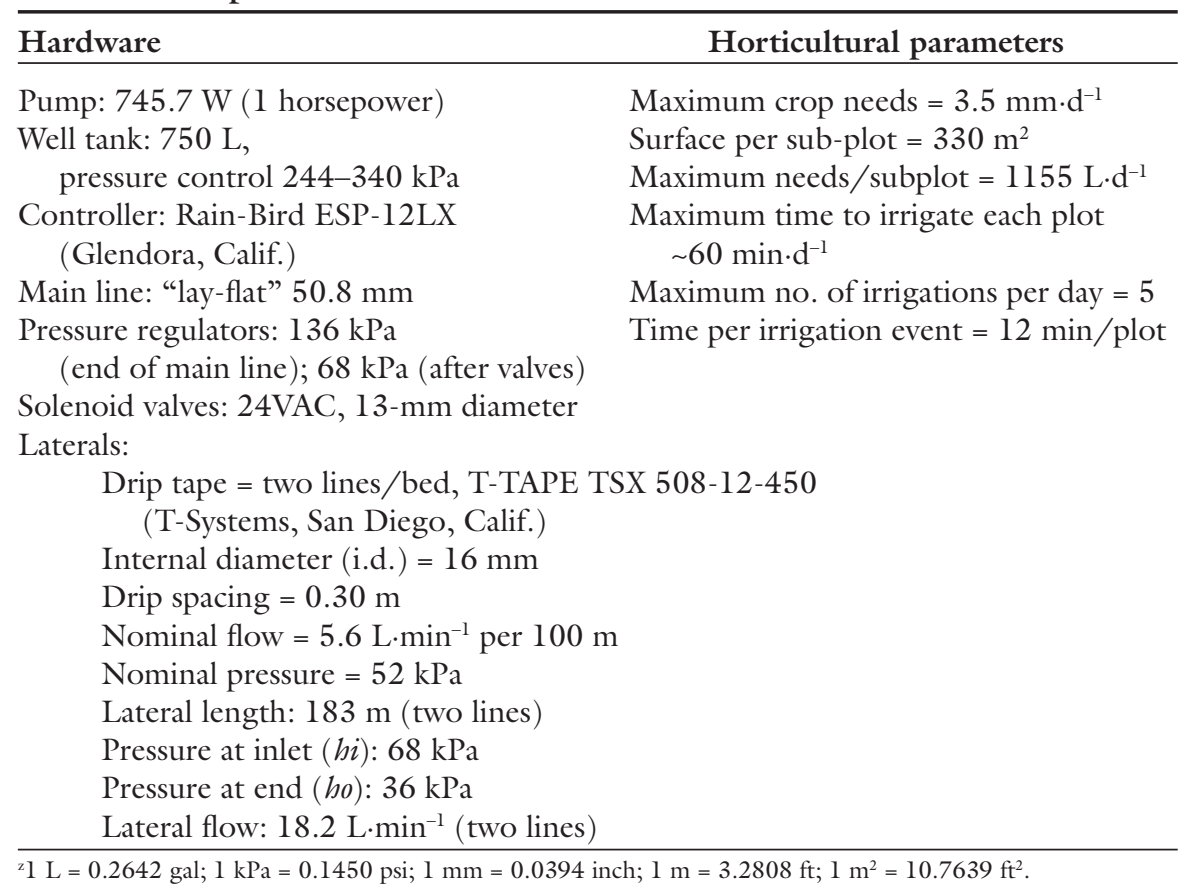

by adding extra irrigation events off the preset timer schedule (early morning), to apply equal amounts of water and chemicals for all treatments. Tomatoes were cultured and protected according to local agronomic practices. Pre-plant dry fertilizer $(6 \mathrm{~N}-2.6 \mathrm{P}-10 \mathrm{~K})$ at 1431 $\mathrm{lb} /$ acre was rototilled into the bed. Dissolved fertilizer $(4 \mathrm{~N}-0 \mathrm{P}-6.7 \mathrm{~K})$ was applied weekly at $18 \mathrm{lb} /$ acre during each of the final 5 weeks prior to harvest. There was a 2 -week delay of the systemic insecticide injection needed to protect plants from transmission of tomato yellow leaf curl virus (TYLCV) by whiteflies (Bemisia spp.), and in initiating fertigation. The delay was caused by equipment difficulties. The first tomato harvest occurred on 21 Apr. 2003 followed by the second and final harvest 2 weeks later, resulting in a $76-\mathrm{d}$ season.

IRRIGATION TREATMENTS. Seven irrigation treatments, each with three replicates, were established on beds 600 $\mathrm{ft}$ long (Fig. 1 and Table 2). Treatments tl-t6 were LVHF. All replications, except those for time-based treatments ( $\mathrm{t} 5$ and $\mathrm{t} 6$ ), were controlled independently by a commercially available time based irrigation controller (ESP Series; Rain Bird, Inc., Glendora, Calif.) by means of a solenoid valve (Table 1 ). A water meter and pressure regulator were installed at the entrance of the drip lines. An electrical pump in line with a pressurized tank maintained pressure in the system. Table 1 provides details of the design of the irrigation system installed in the plot. The soil moisture sensors were installed $100 \mathrm{ft}$ from the solenoid valve, between plants, in the center of the bed and wired in closed loop control with the irrigation timer (Zazueta et al., 1994) according to the manufacturers' specifications. The low-tension switching tensiometers used (model TGA-LT; Irrometer Co., Riverside, Calif.) contain an adjustable tension level selector mounted on top of the tensiometer gauge that was set to the desired tension (read directly on the gauge, 10 and $15 \mathrm{kPa}$ for $\mathrm{tl}$ and $\mathrm{t} 2$, respectively). When the gauge needle falls below the set point (wetter soil) the magnetic relay in the selector opens (irrigation override). The GMS were

Table 2. Description of the irrigation treatments, soil moisture based sensor control, and soil moisture thresholds used in this research.

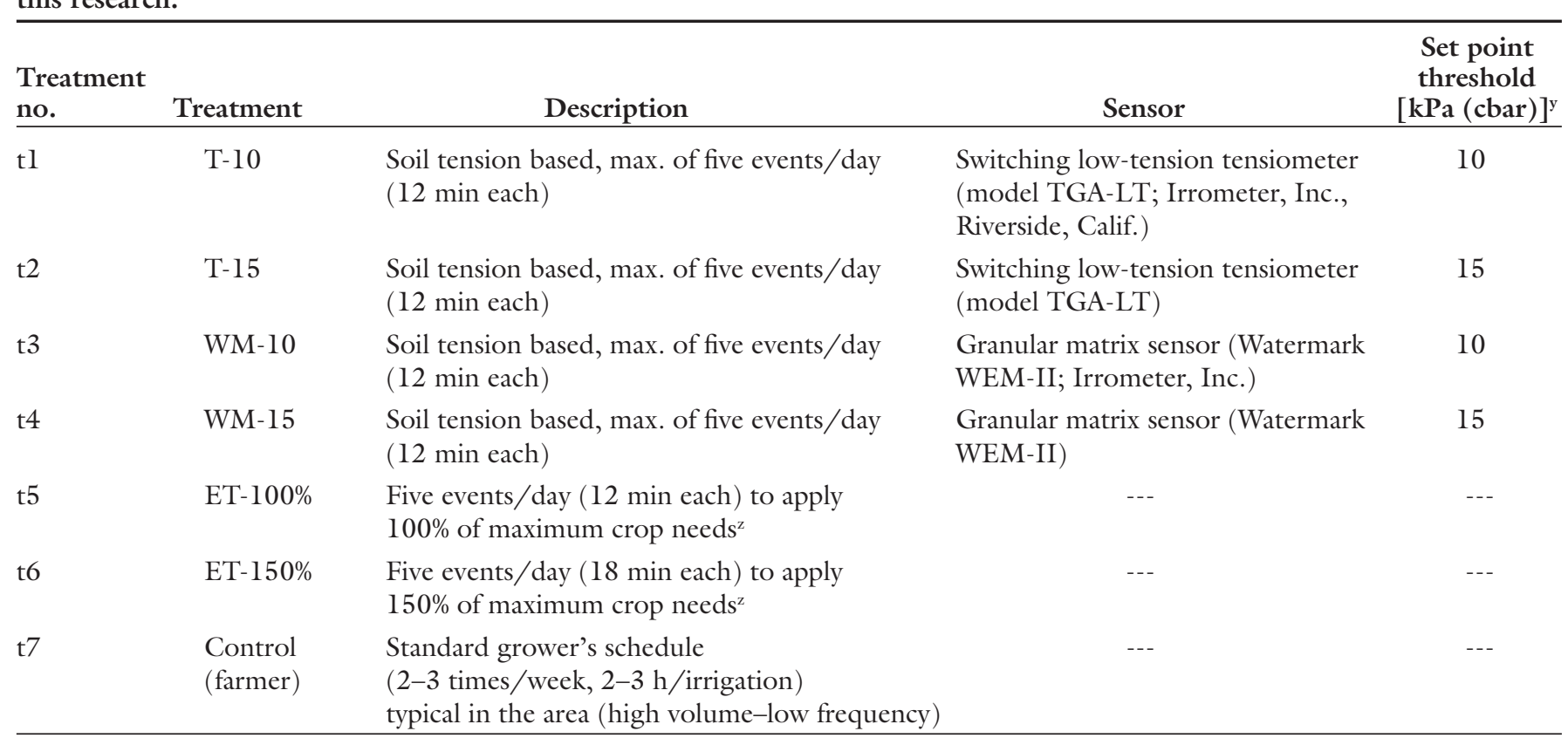

${ }^{\mathrm{z}}$ Based on maximum tomato water needs for Miami (Simonne et al., 2001). 
interfaced with proprietary electronic modules (WEM II; Irrometer Co.) that contained an adjustment dial to set differing soil moisture levels [i.e., wet $=$ positions 1 to $4(10$ to $25 \mathrm{kPa})$; intermediate $=$ positions 5 to 8 (35 to $70 \mathrm{kPa})$; dry $=$ positions 9 to 11 ( 85 to $120 \mathrm{kPa})$ ]. Positions 1 and 3 (10 and $15 \mathrm{kPa}$ ) were selected for treatments $\mathrm{t} 3$ and $\mathrm{t} 4$, respectively, based on initial testing in the laboratory with the field soil. With both systems the timer is overridden (i.e., current is not sent to the valve and the solenoid valve remains closed) if sufficient soil water is available (matric potential less than 10 or $15 \mathrm{kPa}$ ). Irrigation windows were established based on treatment t5 [ET-100\% (i.e., five events/day for each sensor based replication)] corresponding to the crop maximum water requirement (ET) for tomatoes recommended in the Miami area based on historical ET estimates (Simmone et al., 2001). A significant volume of water can potentially be saved with this system during periods of reduced plantwater needs, and the moisture kept at optimal levels in the root zone.

WATER USE AND YIELD ANALYsis. Water use in each treatment was continuously recorded by a positive displacement water meter equipped with a magnetically actuated reed switch [PSM-T $(5 / 8 \times 1 / 2$ inch $) ; \mathrm{ABB}$ Water Meters, Ocala, Fla.] connected to an event data logger (H7-002-04; Onset Computer Corp., Bourne, Mass.). Weekly readings were also manually taken from the counters in each water meter. Values obtained from replications in each treatment were averaged.

Harvest was carried out in $183-\mathrm{ft}^{2}$ subplots of 15 plants each distributed along the center row of each treatment. Eight subplots were harvested for treatments $\mathrm{tl}-\mathrm{t} 4$, and three subplots for $\mathrm{t} 5 \mathrm{-t} 7$. Fruit were graded following Florida Tomato Committee Standards (Brown, 2000) and were segregated into extra-large, large, medium and culls after each harvest, to calculate the marketable and total fruit yields. Data were analyzed by analysis of variance and means were compared using Duncan's multiple range test at the $5 \%$ level of significance (SAS Institute, Cary, N.C.).

\section{Results and discussion}

WATER USE. Irrigation water use results are summarized in Table 3 .

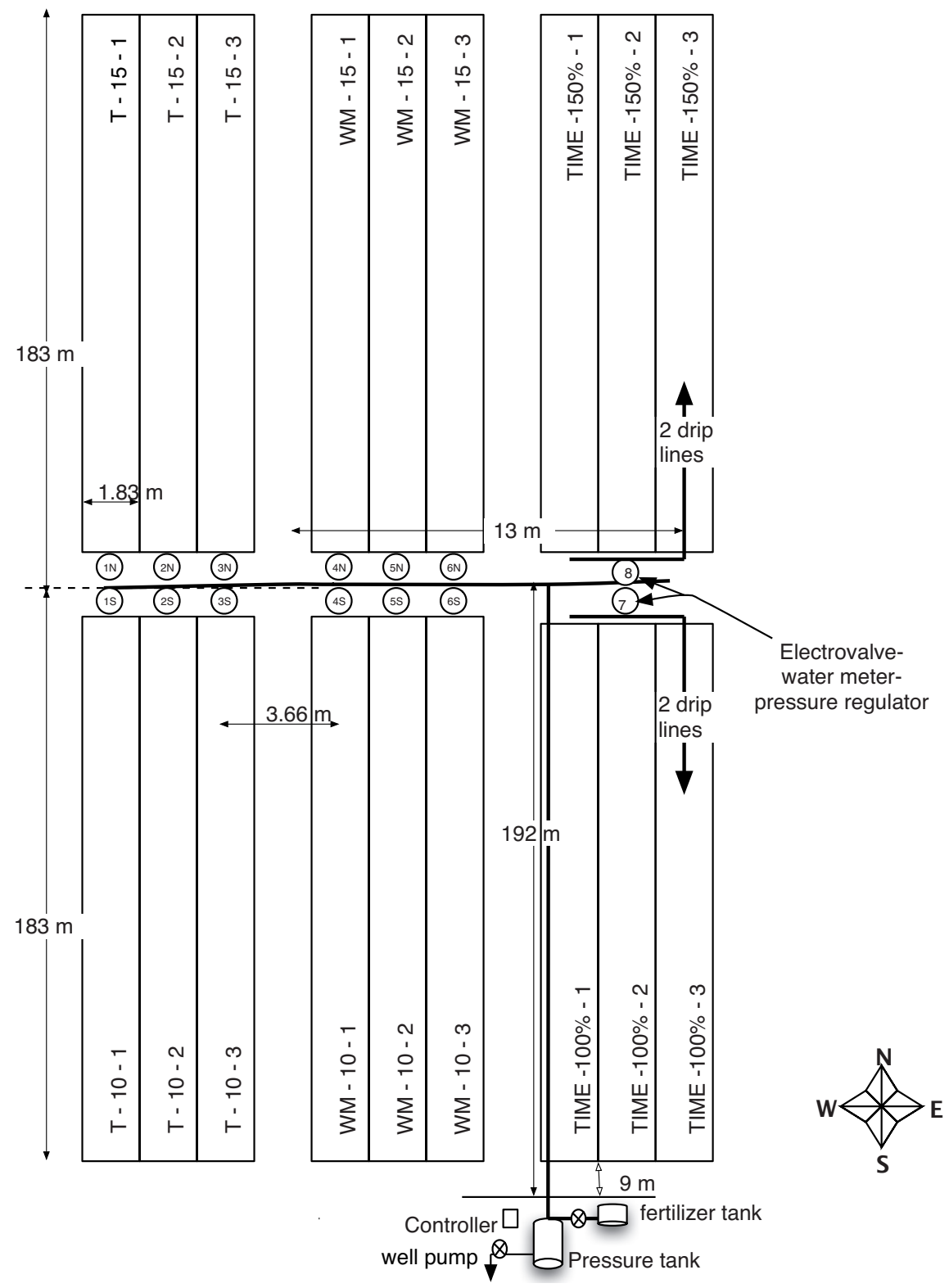

Fig. 1. Tomato plot layout showing irrigation experimental treatments with three replications, where the control (farmer's tomato field) continues on both sides of the plot $(1 \mathrm{~m}=3.2808 \mathrm{ft})$.

Table 3. Total water use over the tomato season and comparison to the commercial field irrigation and evapotranspiration based treatments.

\begin{tabular}{|c|c|c|c|c|}
\hline No. & Treatment $^{\mathrm{y}}$ & $\begin{array}{l}\text { Water } \\
\text { applied } \\
(\mathrm{mm})^{\mathrm{x}}\end{array}$ & $\begin{array}{c}\text { Percent } \\
\text { change }^{\mathrm{z}} \text { from } \\
\text { control }(\mathrm{t} 7)\end{array}$ & $\begin{array}{c}\text { Percent } \\
\text { change from } \\
\text { ET based (t5) }\end{array}$ \\
\hline $\mathrm{tl}$ & Tensiometer at $10 \mathrm{kPa}(\mathrm{T}-10)$ & 112 & -67 & -39 \\
\hline t2 & Tensiometer at $15 \mathrm{kPa}(\mathrm{T}-15)$ & 91 & -73 & -51 \\
\hline $\mathrm{t} 3$ & GMS at $10 \mathrm{kPa}(\mathrm{WM}-10)$ & 182 & -46 & -2 \\
\hline $\mathrm{t} 4$ & GMS at $15 \mathrm{kPa}$ (WM-15) & 172 & -49 & -7 \\
\hline $\mathrm{t} 5$ & $100 \%$ of maximum crop needs (ET-100\%) & 185 & -45 & --- \\
\hline t6 & $150 \%$ of maximum crop needs (ET-150\%) & 262 & -22 & +42 \\
\hline t7 & Control (farmer) & 335 & --- & +81 \\
\hline
\end{tabular}

${ }^{2}$ Change $=100 \times \frac{\text { Treatment }- \text { Control }}{\text { Control }}$

v $1 \mathrm{kPa}=1$ cbar.

${ }^{\mathrm{x}} 1 \mathrm{~mm}=0.0394$ inch. 


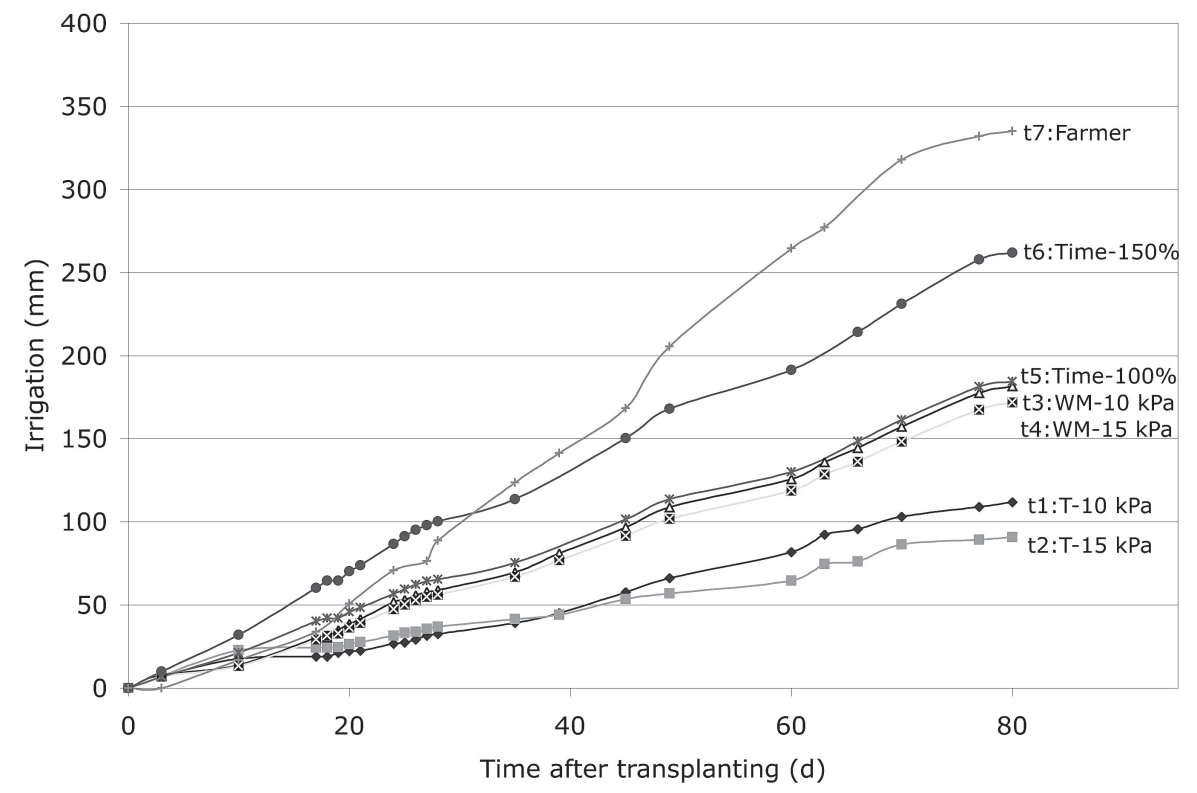

Fig. 2. Average cumulative water applied in each automatic irrigation treatment and control during the tomato season $(1 \mathrm{~mm}=0.0394$ inch; $1 \mathrm{kPa}=1 \mathrm{cbar})$.

Treatments tl-t6 used substantially less water than traditional irrigation in the commercial field control (t7). The automated system with switching tensiometers $(\mathrm{t} l-\mathrm{t} 2)$ reduced water use the most ( $67 \%$ to $73 \%)$. A change in the moisture set point (soil tension above which the irrigation is allowed to start) for this sandy soil, from 10 to $15 \mathrm{kPa}$, reduced irrigation 19\% (112 to $91 \mathrm{~mm}$ ) with tensiometers but only $5 \%$ (183 to $173 \mathrm{~mm}$ ) with GMS based irrigation (Table 3 ). Timer-based LVHF with no sensors ( $\mathrm{t} 5-\mathrm{t} 6$ ) also conserved water by limiting over-irrigation that was evident on the producer treatment. The standard commercial schedule (t7) used about $81 \%$ more water than the maximum crop water needs for the area (ET-100\%, treatment $5)$. Compared to irrigation based on maximum crop water needs (t5), as shown in the last column of Table 3 , the tensiometer-based treatments $(\mathrm{t} \mathrm{l}-\mathrm{t} 2)$ resulted in a substantial decrease in water use $(39 \%$ to $51 \%)$ while use of the GMS based system (t3-t4) did so only marginally ( $2 \%$ to $7 \%$ ). The maximum recommended crop water requirement (Simmone et al., 2001) was calculated based on the measured long-term reference evapotranspiration (ETo) and crop coefficients (Kc) for tomatoes in the area. However the recommendations do not consider soil moisture storage, and in these shallow soils relatively high volume irrigation events every few days will exceed the soil water storage capacity. The water savings obtained with the tensiometer soil moisture based irrigation strategy are due to application of water in small amounts to match the soil water holding capacity depending on how much is withdrawn by the plants. The results show that drip irrigation based on soil water tension can result in irrigation volume less than maximum crop water requirements calculated by historical ET.

The main water savings obtained with the tensiometers occurred from 10 to $40 \mathrm{~d}$ after transplanting (DAT; Fig. 2). This time period corresponds to the time when the plants are small and water demands are low. During this time, the soil remained wet (above 10 and $15 \mathrm{kPa}$ for $\mathrm{tl}$ and $\mathrm{t} 2$, respectively) between irrigation events and the sensors blocked most of the scheduled events in $t l$ and $t 2$ (potential of up to five events /day) compared to time based treatments and control ( $\mathrm{t} 5-\mathrm{t} 7)$. This is shown in Fig. 2 by diverging lines during that period. In addition, tl-t2 have flatter water use slopes after 60 DAT which indicates that plant water needs stabilized at the end of the season.

Crop yields. Tomato yields at the experimental plots ( $\mathrm{tl}-\mathrm{t} 6)$ were not significantly different to those of the control (t7), except for the wettest time-based treatment, ET-150\% (t6; Table $4 ; \alpha=0.05)$. In $\mathrm{tl}$ and $\mathrm{t} 3-\mathrm{t} 7$, yields were similar to the Florida average of 34,300 lb/acre (Maynard, 2001) and similar to average yields in Miami-Dade County of 35,100 $\mathrm{lb} / \mathrm{acre}$ (Li et al., 2002). The farmer field ( $\mathrm{t} 7)$ had more extra-large fruit than $\mathrm{t} 1 \mathrm{-t} 3$ and t6. Although not sta-

Table 4. Tomato yield and grades obtained for the total harvest from each experimental treatment.

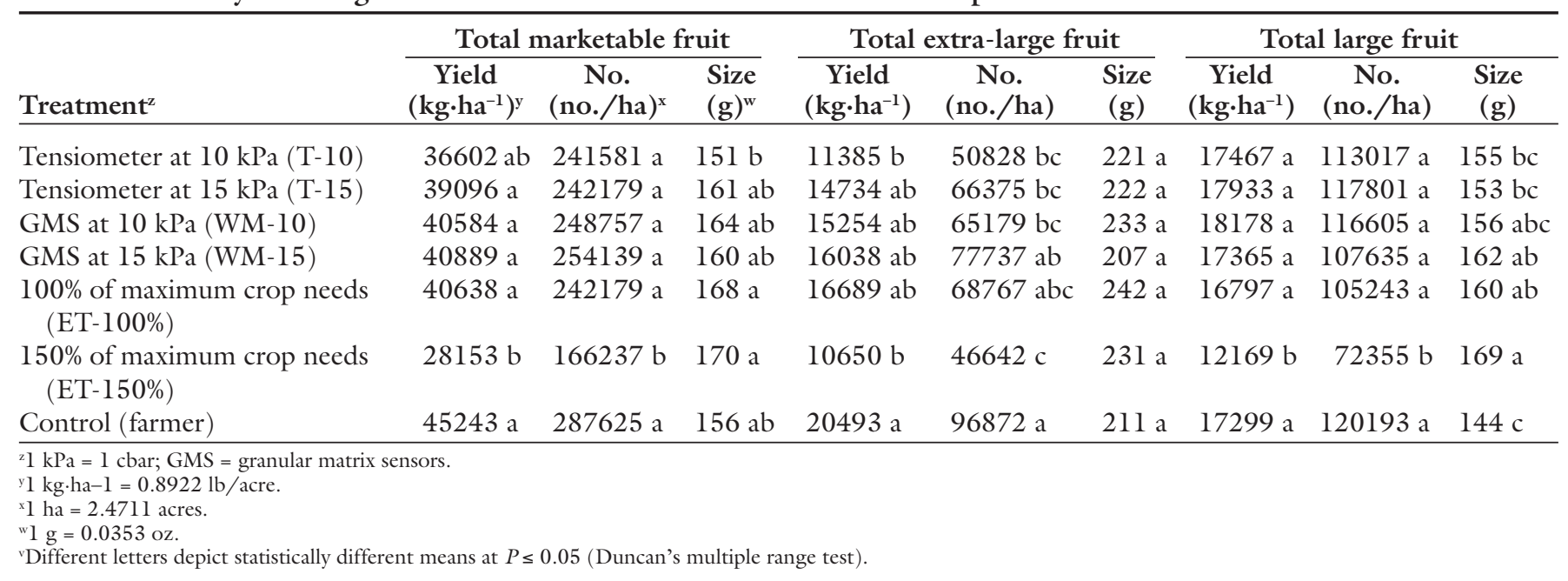


tistically significant, the experimental plot yields were numerically lower than that of the control grower's surrounding farm. This could be explained by the following: 1 ) the lower rate of dry fertilizer incorporated into the experimental beds ( $1430 \mathrm{lb} / \mathrm{acre})$ than in the commercial beds (1590 lb/acre) following recommendations for the area (Li et al., 2002); 2) a greater TYLCV incidence observed in the experimental plots than in the farmer field; and 3) the delay in initiation of fertigation with respect to the control. The greater TYLCV incidence was caused by the 2 -week delay in injecting the systemic insecticide needed to protect the plants from infection by whiteflies.

Despite the large reduction in water use in $\mathrm{tl}-\mathrm{t} 6$ with respect to the control, there was not a large impact on fruit quality (Brown, 2000). Although the wettest treatments (Time-150\% and $\mathrm{T}-10 \mathrm{kPa}$; $\mathrm{t} 6$ and $\mathrm{tl}$, respectively) also yielded the fewest large and extralarge fruit, the automatic irrigation system controlled by the switching tensiometer at $15 \mathrm{kPa}$ yielded the highest large and extra-large yield as well as overall yield while conserving $73 \%$ of the water compared to the standard commercial irrigation practice ( $\mathrm{t} 7$ ). This same treatment reduced water use approximately $\mathbf{5 0} \%$ compared to irrigation based on the area's maximum recommended crop water needs ( $\mathrm{t} 5)$. Although $\mathrm{tl}-\mathrm{t} 4$ resulted in less irrigation applied compared to the maximum crop requirement based on historical ET data ( $\mathrm{t} 5$ ), crop yields were not negatively impacted. The high water use efficiency obtained by high frequency low volume soil moisture (tensiometer) based drip irrigation $(\mathrm{tl}-\mathrm{t} 2)$ for this crop can be explained in terms of: 1 ) monitoring moisture and applying water in just the small volume of soil where the crop roots are contained in our conditions (bed width and shallow depth to rock layer); and 2) supplying the crop water needs in limited (but physiologically sufficient at $15 \mathrm{kPa}$, Wang et al., 2004) quantities on a close to real-time mode. This rapid response of the system to plant water needs, as dictated by radiation, temperature, relative air humidity, wind, plant phenology, etc., is a powerful water-saving feature of the method.

ASSESSMENT OF WATER SENSORS and treatments. Tensiometers, when subject to weekly maintenance, performed well and consistently for each treatment $(<7.5 \%$ water use differences across replicates). However, if left unattended for more than 1 week, air entered the tensiometers, breaking the water column. This was more frequent in the driest treatment $(15 \mathrm{kPa})$ after which twice weekly maintenance (Monday and Friday) was adopted. From a practical point of view it is essential in southern Florida field conditions to include routine maintenance of tensiometers. This routine consists of opening the tensiometer, refilling the column, pumping to purge air bubbles and recapping. Preferably this should be done at least one hour before the first daily irrigation set-time or after the last one to give sufficient time for the soil and the tensiometer to equilibrate before the next irrigation. Care should be taken not to break the tensiometer contact with the surrounding soil by twisting when uncapping for refilling. A de-aerated solution of water boiled for 20 min with a few drops of algaecide (unscented household bleach) gives the best results. Two of the tensiometers had to be replaced during the season. One was accidentally punctured when staking the tomatoes and the other one had a faulty seal that made it discharge frequently.

The granular matrix sensor based irrigation system performed erratically across repetitions and treatments. Two characteristics of GMS-based irrigation system contribute to these results. First, the low set points needed for this coarse soil (15-25 kPa) are close to the lower limit of usability for these sensors $(7 \mathrm{kPa})$. Second, the sensors exhibit a marked delay in responding to quick soil moisture changes typical of high frequency irrigation, especially during re-wetting phases. In addition, the commercial system used here includes an interface box with a dial on a scale from 1-11 (and an OFF position to by-pass the sensor). The same dial setting in the three replications of each treatment gave very different soil moisture readings from tensiometers installed just $10.2 \mathrm{~cm}$ ( 4 inches) from the GMS. Also, consecutive steps in the dial scale (from 1 up) did not correspond to the increases in field soil tension given by the manufacturer. As a result, although about $50 \%$ water savings were observed with respect to the control (commercial farm, t7), no appreciable difference in water savings was found between the 10 and $15 \mathrm{kPa}$ treatments (settings 1 and 3 in the dial scale). Furthermore, compared to the ET- $100 \%$ treatment only $2 \%$ to $7 \%$ water savings were observed. In fact, since the granular matrix sensors were interfaced with the timer pre-set with the same schedule as that for 5 , i.e., five irrigation events per day of 12 min each, these results indicate that the system failed to override irrigation events (Fig. 2). In addition, two interface boxes had to be replaced during the season after they stopped working spontaneously. The LVHF time-based treatments ( $\mathrm{t} 5$ and $\mathrm{t} 6$ ) performed well, without requiring any maintenance.

\section{Conclusions}

One year of yields for tomatoes irrigated with an automated irrigation system based on feedback from tensiometers and GMS were not different than those achieved with standard commercial irrigation scheduling practices and reduced total applied water by up to $73 \%$. Switching tensiometers at $15 \mathrm{kPa}$ performed the best. The high efficiency in water use obtained is explained in terms of the rapid response of the irrigation system to plant needs, as well as the limited soil volume targeted by the method. A substantial reduction in deep percolation and in ensuing chemical transport is expected. Although water savings were obtained with the application of the low volume-high frequency concept (applying water to meet $100 \%$ of the maximum crop water needs in small quantities several times per day), these savings were increased when irrigation was automatically controlled with soil moisture sensors. However, not all sensors tested performed the same. Routine maintenance (refilling and pumping) was critical for reliable operation of the switching tensiometers, especially on the driest treatment of $15 \mathrm{kPa}$ (twice per week in our conditions). The granular matrix sensor based irrigation system behaved somewhat erratically and did not improve water savings compared to the case where $100 \%$ of the maximum plant water needs were applied with a LVHF system set for five daily irrigation events (12 min each) with no sensors.

\section{Literature cited}

Augustin, B.J. and G.H. Snyder. 1984. Moisture sensor controlled irrigation for maintaining bermudagrass turf. Agron. J. 76(5):848-850. 
Brown, R. 2000. Florida Tomato Committee Regulat. Bul. No. 2. Florida Tomato Committee, Orlando.

Clark, G.A., C.D. Stanley, and D.N. Maynard. 1994. Tensiometer control vs. tomato crop coefficients for irrigation scheduling. ASAE Paper No. 94-2118. Amer. Soc. Agr. Eng., St. Joseph, Mich.

Dukes, M.D., E.H. Simonne, W.E. Davis, D.W. Studstill, and R. Hochmuth. 2003. Effect of sensor-based high frequency irrigation on bell pepper yield and water use, $p$. 665-674. In: Proc. 2nd Intl. Conf. Irr. and Drainage, 12-15 May, Phoenix, Ariz.

Hansen, R.C. and C.C. Pasian. 1999. Using tensiometers for precision microirrigation of container-grown roses. Appl. Eng. Agr. $15(5): 483-490$.

Irmak, S. and D.Z. Haman. 2001. Performance of the Watermark granular matrix sensor in sandy soils. Appl. Eng. Agr. 17(6):787-795.

Li, Y.C., H. Bryan, W. Klassen, M. Lamberts, and T. Olczyk. 2002. Tomato production in Miami-Dade County, Florida. Fact-sheet HS-858, Florida Coop. Ext. Serv., Inst. Food Agr. Sci., Univ. of Florida. 24 Oct. 2004. <http://edis.ifas.ufl.edu/ TR014>.

Li, Y, R. Rao, H. Bryan, and T. Olczyk. 1998. Optimized irrigation schedule to conserve water and reduce nutrient leaching for tomatoes grown on a calcareous gravelly soil. Proc. Fla. State Hort. Soc. 111:58-61.

Maynard, D.N. 2001. Yields of vegetables, p. 89-90. In: D.N. Maynard and M. Olson (eds.). Vegetable production guide for Florida. Vance Publ., Lenexa, Kans.
Meron, M., R. Hallel, G. Shay, R. Feuer, and R.E. Yoder. 1996. Soil sensor actuated automatic drip irrigation of cotton, p. 886-891. In: C.R. Camp and E.J. Sadler (eds.). Evapotranspiration and Irr. Scheduling Proc. of the Intl. Conf., San Antonio, Texas. Amer. Soc. Agr. Eng., St. Joseph, Mich.

Muñoz-Carpena, R., Y. Li, and T. Olczyk. 2002. Alternatives for low cost soil moisture monitoring devices for vegetable production in the South Miami-Dade County agricultural area. Fact Sheet ABE 333, Dept. Agr. and Biol. Eng., Univ. of Florida. 24 Oct. 2004. <http://edis.ifas. ufl.edu/AE230>.

Muñoz-Carpena, R., A. Ritter, and D.D. Bosch. 2004. Field methods for monitoring soil water status, p. 167-195. In: J. Alvarez-Benedi and R. Muñoz-Carpena (eds.). Soil-water-solute process characterization. CRC Press, Boca Raton, Fla.

Qualls, R.J., J.M. Scott, and W.B. DeOreo. 2001. Soil moisture sensors for urban landscape irrigation: Effectiveness and reliability. J. Amer. Water Resources Assn. 37(3):547-559.

Shock, C.C., E.B.G. Feibert, L.D. Saunders, and E.P. Eldredge. 2002. Automation of subsurface drip irrigation for crop research, p. 809-816. In: F.S. Zazueta and J. Xin (eds.). Proc. World Congr. Computers in Agr. and Natural Resources, 13-15 Mar. 2002, Iguacu Falls, Brazil.

Simonne, E.H., M.D. Dukes and D.Z. Haman. 2001. Principles and practices of irrigation management for vegetables, $\mathrm{p}$. 31-37. In: D.N. Maynard and M. Olson (eds.). Vegetable production guide for Florida. Vance Publ., Lenexa, Kans.
Smajstrla, A.G. and R.C. Koo. 1986. Use of tensiometers for scheduling of citrus irrigation. Proc. Fla. State Hort. Soc., 99:51-56.

Smajstrla, A.G. and S.J. Locascio. 1994. Irrigation cutback effects on drip-irrigated tomato yields. Proc. Fla. State Hort. Soc., 107:113-118.

Smajstrla, A.G. and S.J. Locascio. 1996. Tensiometer-controlled drip irrigation scheduling of tomato. Appl. Eng. Agr. 12:315-319.

USDA. 1996. Soil survey of Dade County area, Florida. USDA-NRCS, Washington, D.C.

Wang, Q., W. Klassen, A.A. Abdul-Baki, H.H. Bryan, Y.C. Li, and M. Codallo. 2004. Influence of summer cover crops and irrigation rates on tomato yields and quality in a subtropical area. Proc. Fla. State Hort. Soc. 116:140-143.

Zazueta, F.S., A.G. Smajstrla, and G.A. Clark. 1994. Irrigation system controllers. Fact Sheet SS-AGE-22, Dept. of Agr. and Biol. Eng., Florida Coop. Ext. Serv., Inst. of Food and Agr. Sci., Univ. of Florida. 24 Oct. 2004. <http://edis.ifas. ufl.edu/AE077>.

Zazueta, F.S. and J. Xin. 1994. Soil moisture sensors. Bul. 292, Florida Coop. Ext. Serv., Inst. Food and Agr. Sci., Univ. of Florida. 24 Oct. 2004. <http://edis.ifas. ufl.edu/EH226>. 